\title{
The Experiences of Fighting against Non-action at All Times and in All Countries Jie $\mathrm{Gu}^{1, \mathrm{a}}$,Quanliang $\mathrm{Mei}^{1, \mathrm{~b}}$ and Song $\mathrm{Mei}^{1,2, \mathrm{c}}$
}

\author{
1.School of Literature, Law and Economics, Wuhan University of Science and Technology, \\ P.R.China \\ 2. Hubei Institute of Administrator, P.R.China \\ agujie0101@126.com, ${ }^{b}$ meior1996@163.com, ${ }^{c}$ meisong@126.com
}

\begin{abstract}
Keywords: non-action; ancient management government officials; modern civil servant system; legislation-based governance
\end{abstract}

Abstract. As a negative cultural administration phenomenon, non-action exists at all times and in all countries. In ancient China, to fight against non-action is mainly based on the idea of "ruling by man", supplemented by the idea of "ruling by law", through the election system and the imperial examination system to select government officials and talents who have ability and political integrity and make a difference; to examine officials’ performance through performance appraisal as the core of the test system; to punish or derogate the one who holds onto his job while failing to fulfill his responsibility, who has non-action and doesn't have any actual performance on the basis of the examination results so as to encourage government officials to take a positive action; to supervise the government officials' power and actions and to punish their illegal acts through independent institutions, rigorous system and a weighted ancient supervisory system. Western countries govern the non-action behavior in strict accordance with the law and the civil service system and build up the civil servant system on the basis of "rule by law", which provides protection of the legal system for western countries to govern the non-action performance.

Since the 18th National People's Congress of Communist Party of China, in the context of running the party strictly and with the release of the eight-point regulations, the state has stepped up great efforts to fight corruption, especially the accountability system for leading cadres is gradually established and implemented. A small number of government employees either do not or are unable to fulfill their duties, or behave irresponsibly as the main feature of non-action behavior, the subjective performance as "mediocre administration", "sloth administration" and "inactive administration", the concrete performance as the following six non-action phenomena "make fashion characterized by asking for stability while avoiding risks; sing tune by shouting slogans while doing nothing; dawdle by being reconciled to the situation while being mediocre and incompetent; roundabout by evading contradictions when confronting problems; throw up the job when they suffer hardships and dangers and are unable to bear the burden; cover up the truth by deceiving their superiors and deluding their subordinates" ${ }^{[1]}$. Non-action behavior as a negative energy cultural administration phenomenon spread in the leading cadres at all levels, is bound to affect the working enthusiasm of overall national civil servants in the point of current social and economic reform, if we do not treat it on time or allow its development, which will exert a bad influence on the team building of civil servants in our country, and then seriously affect the social and economic development.

The non-action behavior of some leading cadres is no longer a negative cultural administrative phenomenon to current society in China, Derivatives as the traditional bureaucratic system brings at all times and in all countries. Efforts to prevent and control non-action have also been an important content of the management system at all times and in all countries. After thousands of years of history accumulating, China and overseas countries have accumulated a lot of valuable experience worthy of learning. 
1. The content of governing non-action in ancient China includes: ensuring the leading role of "rule by man" supplemented by "rule by law" as the ancient officials management system

To run the state well, we must run the government officials well first. Government officials are the basic outline of people, which is the consensus of many politicians in history. The legitimate political system of feudal monarchy determines that ancient China must be "rule by man" , and in ancient dogmatic system, the implementation of "rule by man" is the core of the "government official". More than 5000 years of Chinese civilization, the management system of China officials which regards government officials as the core of the system has a long history, from the main officials selection system represented by the election system and the imperial examination system to the official examination system represented by examining the courses, and then to the disciplinary system to monitor the official, all of these constitute the complete system of official management system for the ancient China to prevent and control of the non-action behavior. In the official management system of the Chinese traditional "ruling by rites", "ruling by virtue" and "ruling by humanity" and "ruling by man" thought has always been dominant, and "rule by law" is always in a secondary position.

1.1 Government official selecting system represented by recommendation and interview system and imperial examination system, aims to choose talents with integrity and ability.

1.1.1 Recommendation and interview system VS regulation over non-action.

Select government officials through recommendation of talent personnel to participate in state governance. It is a bottom-up recommendation system, established by Emperor Wu of the Han Dynasty in the first year of Yuang Guang. Strictly, the recommendation and interview system in Han Dynasty began from Emperor Wen, who ordered that "recommending talents who are integrity and straight to give advice", and set up "interview institution" (examination institution). It is featured by recommendation and examination before recruiting.

\subsubsection{Imperial examination system VS regulation over non-action.}

Select government officials with ability and integrity through examination to participate in state governance. First introduced in the Northern and Southern Dynasties, this system establishes and develops through Sui Dynasty, Tang Dynasty, and Song Dynasty, and continues to hold place in Yuan Dynasty, Ming Dynasty and Qing Dynasty. During its 1300 years history, it has helped the feudal rulers choose numerous loyal, honest and upright officials, playing a positive role in effectively arranging feudal politic activities. In this examination system, subjects are chosen by the government, and scholars may take the examination without any restraints. The choice of officials depends on their examination performance, which is the major characteristic of imperial examination system ${ }^{[2]}$. With public examination and selection through exam results, it becomes the major approach to recruit officials in the middle and later period of feudal society in China, which symbolizes that China's way of selecting officials has been the most objective and fairest one that human society can achieve at that time since the middle period of feudal society.

The common characteristic of the recommendation and interview system and the imperial examination system which has been existing for more the 1300 years, is that talents are selected through recommendation and examination or imperial examination. That is "selecting talents with ability and integrity", which are the crucial criteria for the recruitment. In other words, those talents are strictly selected before they become government officials. Therefore, it ensures people who are lack of capability will not be in the government office, while those selected ones can resist corruption, devote to governance, love people, give full play of their talent, and make achievements, safeguarding the interest and power of the ruling class.

1.2 This appraisal system central by performance evaluation focuses on the performance of officials. And the evaluation result is the foundation for punishment and delegation of those officials who neglect their duties, or do not perform well, so as to promote government officials to carry out their duties.

1.2.1 The specification of appraisal institution.

In ancient China, the appraisal institution is also called the institute for performance evaluation 
or examination. Dating back to the Western Zhou Dynasty, it is gradually established in the Tang Dynasty and introduces the responsibility system to effectively evaluate the performance of officials $^{[3]}$. In the Song Dynasty, the appraisal institution is independent from the Board of Civil Official, composed of the institute of official examination and institute of appraisal. The former mainly evaluates central governmental officials and high-level local officials, while the latter stuffs and county officials. This separation makes the division of work and duty clearer, specifying the evaluation standards and turning out to be fruitful. In the Ming Dynasty, the evaluation institution again becomes a part of the Board of Civil Official, and an additional department for performance appraisal is established to evaluate officials according to their ranks, further developing and improving the evaluation institution and legislation. The Qing Dynasty continues to use this system, preserving the department and adding amore systemic institution to control and govern the evaluation of nationwide officials of all levels.

\subsubsection{The contents of the merit system stress work performance.}

Ancient Chinese rulers attach great importance to determine the contents of the merit system; they not only pay attention to the comprehensiveness of them, but also make the focal points stand out. The important content to assess the officials is their performance. In the Western Zhou Dynasty, the merit contents triennially are "With the Enlightenment of neighbors, justice administration, and evaluation of habitation, cattle, and the number of weapons, to the implementation of the decree.”(Zhou Li·DiGuanSiTuVol.7)To the Qin, Han, Southern and Northern Dynasties, the merit contents have become more and more completed, and the performance is still an important standard to assess the officials. In the Tang Dynasty, "the four goodness and the twenty-seven best" are the contents of the merit and also the highest standard. "The four goodness" means the officials should be saintlike, incorruptible, just and diligent, which are the general requirements for their personal qualities, working styles and attitudes. "The twenty-seven best" are different requirements based on officials' different work natures and responsibilities, which belong to the merit contents of their achievements. As for officials in prefectures and counties, besides the "the four goodness and the twenty-seven best”, their economic achievements are especially assessed. From Song Dynasty and Jin Dynasty to Ming Dynasty and Qing Dynasty, the merit contents become more comprehensive. In order to strengthen the central imperial power, they add "morality" to the merit contents, besides the work performance that the rulers of the past dynasties pay attention to; however, the aspects of ability, diligence and achievement are still the key points of supervision.

1.2.3 The merit standards not only have a general standard, but are also based on the circumstances.

Chinese ancient standards and contents to assess the officials are made according to their different positions and duties, which embody the idea of classified management.In addition to the division of duties, there are unified standards for the officials, which are integrity, achievement, diligence, honesty and other basic requirements.

\subsection{The independent, strict and powerful ancient Chinese supervisory system supervises officials' power and behavior, and also punishes their nonfeasance and illegal actions.}

\subsubsection{Independent supervisory organization.}

The supervisory organ is set up alone, and self-contained, which is directly answerable to the emperor, and is used to supervise officials all over the country. The independence of the supervisory organs has increased over time. In the Ming Dynasty, the censor organization has become one of the three national institutions, "the censor is responsible for picketing, and the court discipline is all dependent on it”. In the Qing Dynasty, in order to give a full play to the supervisory organizations' supervise on officials; the Court of Censors has become the central leading organization of supervision, and its social status is much higher and functions of supervision are more concentrated. 1.3.2 Strict supervisory system.

Liubu (generic terms of the departments of Ministry of Civil Appointment, Ministry of Revenue, Ministry of Rites, Ministry of War, Ministry of Punishment and Ministry of Works) is the hub of the national government, which has always been the focus of the supervision of the supervisory organs. Before the Ming Dynasty, some dynasties already have sent censors to supervise Liubu, but a 
special organization has not been established yet. The Qing Dynasty has adopted Ming Dynasty's method, and set Six Sections in Liubu as the fixed monitoring organization. In addition to their own supervisory duty, each censor supervises their related department respectively, and some important departments are supervised by both the Liubu and the Court of Censors. Anyway, the Censorate has gradually become an independent central supervisory organization. Local supervisory organizations are generally not subject to local control. The supervising institutions and the ultimate power of supervision are directly controlled by the emperor, which facilitate the supervision organs to eliminate interference and improve the efficiency of supervision. Supervising system is radically distributed from top to bottom, and arranged in a crisscross pattern, thus forming a close supervising network.

\subsubsection{Powerful supervisory personnel.}

Both the central and local supervisory officials are powerful. Central supervisory officials are directly on behalf of the imperial power to supervise, although local supervisory officer rank lower, they generally are in a post of seventh rank, but they can still represent the emperor and the imperial court to execute supervision and punishment. With the wide range and authority of their powers, they can supervise with no fear, and can also hamper the higher ones. Their supervisory power can be fully executed.

\subsection{Based on the rule by man, supplemented by the rule by law, which constitute the basis of our ancient official management system}

Throughout the development of the legal system in ancient China, despite the fact that the ruling-by-law thought already existed in ancient China, for example, the very existence of Official Law in the Shang Dynasty, which was used to restrain members of the ruling group and to punish national officials who convicted a crime and their violation or dereliction of duty; and the very existence of Crime of Malfeasance in the Qin Dynasty to punish officials for their dereliction of duty, especially in the late stage of the feudal monarchy, the status of the rule of law in governing officials who neglect their duties has been further improved, for instance, there are provisions to punish officials for their dereliction of duty and oversight in Law of the Ming Dynasty and Law of the Qing Dynasty, however, the ruling-by-law thought is always in the subordinate position in national governance; and the thought of "the rule by man" which has "rule by virtue", "rule by rite", and "rule by benevolence" as its main principles still remains to be primary means for the emperor-centered ruling class to govern the country and manage officials. The thought of "the rule by man" is a reflection of the thought that the power of the emperors in ancient China is given by the heaven or by God. The emperor is the incarnation of God or the heaven, and exercises his ruling power to all his people. All this territory belongs to the king, all the people belongs to the emperor. The officials in the bureaucratic system are only tools to assist emperors to govern the country, with emperors having supreme power and completely above all legal systems. Therefore, the thought of "the rule by man" which has "rule by virtue”, "rule by rite”, and "rule by benevolence" as its main principles forms the basis of official management system in ancient China, and is always in a dominant position, while, the thought of " the rule by law" is only in a secondary position

\section{How western countries deal with non-action officials: the law-based national civil servant system}

\subsection{Civil servant system: the system guarantee to deal with non-action officials}

\subsubsection{Selecting the best by open examination.}

The civil servant system has been very mature and complete in western countries. In many western countries, they regard open competitive examinations and merit-based selection as the core of the civil servant selection system, and also the basis of selecting national public servants, to ensure that under the premise of fair competition, they can select excellent administrators who are capable. In 1870, the Privy Council stipulated expressly that open competitive examinations would be implemented for those who should take the civil servant selection examination, then recruited them on a selective basis from those qualified candidates who have done an internship for half a year to a year. In 1946, French General Rules for Civil Servants formulated a principle that civil 
servants should all take competitive examinations and be recruited on a selective basis. In 1883, American Pendleton Act also made similar rules to ensure that civil servants should pass the open examination and be recruited on a selective basis. The implementation of open examination system really plays an important role in selecting civil servants with ability and can make a difference in their future work. Firstly, in the process of hiring civil servants, the principles of strict control and layers of screening are followed, and thereby those who have a genuine talent and can truly make a difference are sent to the public positions. Secondly, the establishment of the examination system helps the Western countries find an effective way to select talents, helps with the formation of a group of civil servants who are capable, stable, and are of high level, and plays an important role in maintaining a high efficient and continuing administrative system. Therefore, many countries establish the examination system through legislation, and develop a civil servant selection system.

\subsubsection{Intensive training to improve ability.}

All of the countries in the West attach great importance to the training of civil servants which is the main means taken to constantly improve the civil servants' ability of being a competent officer. At the present stage, the annual civil servant training rate is about $1 / 5$ in Japan while in America the annual civil servant training rate reaches $1 / 3$. At the same time, western countries even have made relevant competence standards in the civil servant training. For example, in 1994, the American government made a list of the competences that civil servants of various levels or even of different departments needed, which became the guide of civil servant training and the object of self-improvement. In the early 1990s, the training of senior civil servants was competence-oriented and a uniform competence standard was lie down in British. The training can not only improve the civil servants' competence and quality, but also prevent obsolete knowledge, competence decrease and even the "inaction" phenomenon to some extent.

\subsubsection{Expanding communication \& strengthening vitality.}

To overcome the empirical inertness resulting from civil servants staying a permanent position for a long time as well as to motivate civil servants in new positions to make a difference actively, countries generally adopt the communication system between civil servants in different posts to strengthen their vitality. There are mainly three ways of communication: the transverse flow between the civil servants of the same level within the government, the longitudinal flow between civil servants of different levels while their levels of positions being remained the same, and the flow between government officers and senior executives in enterprises.

2.1.4 Implementing the performance assessment and promotion/demotion is determined according to the results.

On the basis of objectiveness, justice and reasonability, the job performance of the civil servants are being assessed according to their actual performance, and the assessment results will determine whether the civil servants get promotion or demotion, which is the method the western countries generally adopt[4]. Being objective-oriented, they value actual performance, efficiency and outcome, and finishing the task or reaching the effects within a given time is their standard, that is, they value the outcome while neglect the process. Besides, they especially emphasize the incentive role of the assessment result, according to which the rewards or punishments, promotion or demotion, wages and treatments of civil servants are determined. For instance, America especially favor the "preferential promotion" principle, that is, the wages of the civil servants who get outstanding assessment results will be promoted to a higher level, while the civil servants who get dissatisfactory assessment results will receive different punishments according to their degrees, such as salary cut, demotion or deposal. In the western countries, the role of the assessment results is valued and the performance assessment is related with the future and material gains of civil servants who are assessed, which undoubtedly can be a measure to inspire the civil servants to take positive actions and motivate them to voluntarily serve the public[5].

\subsubsection{High salary for clean government.}

A reasonable salary system is not only a powerful guarantee for the civil servants to fulfill themselves dutifully, but also an important measure for the civil servants to keep clean and righteous and stay away from corruption and inaction. Firstly, the high salary for clean government 
policy is extensively adopted in western countries. The civil servant' salary is often positioned above the middle level and the annual outcome of each person is obviously higher than that of employees in manufacturing industry while is slightly lower than that of the employees in high-tech industry as well as large transnational corporations. Secondly, the dynamic adjustment mechanism is implemented. By establishing special organizations to evaluate the level and tendency of the civil servants and adjusting the wage standards in time in accordance with the salary changes of enterprises, the western countries generally adjust salaries dynamically to keep the civil servant' salary level. Thirdly, social welfares are generous. The civil servants' social welfares in the most countries in the west are comparatively generous and extensive, which include insurance welfare, work premium, subsistence allowance, hardship grant and various public facilities welfare.

\subsubsection{Monitoring of anti-corruption, promotion of morality.}

Western countries tend to promote moral standards of civil servants through the monitoring system of anti-corruption, which aims at making civil servants aquatint higher moral standards, avoiding the inaction of government officials, increasing governments' and civil servants' credibility among the public as well as curbing corruption. As for this monitoring system, it contains following aspects: firmly insisting officials to reflecting the ethical values of them, establishing special agents for moral management, consistently implementing training of ethical values, perfecting the system of purifying moralities, upgrading the foundation of public ethic and cultivating good official culture of officials. Among such kind of measures, it is a trend to have administrative ethic based on its legislation. The United States Congress passed the Ethics in Government Act of 1978; furthermore, Congress passed Ethical Behaviors of the US Employees Principle of 1993. In 1994, Canada passed the Conflict of Interest and Behaviors after Demission of Canadian Civil Servants Law. Later, Mexico established Responsibilities of Civil Servants Law. France, Germany, Britain, the Netherlands, Norway, Finland and many other countries have promulgated similar moral code. In 1998, Organization for Economic Co-operation and Development issued "public service ethics management principles" which put forward that to promote ethical conduct in the public service, Member States needed to take action to ensure the good running of institutions and systems. Organization for Economic Co-operation and Development suggested that clear ethical rules and guidelines should be given to public servants. In April, 2001, Japan implemented the "National Public Service Ethics Act".

2.1.7 Penalization of any non-action of officials.

Officials' failure to perform their duties is regarded as concealed and deliberate dereliction, or even unlawful act to some extent. In western countries, certain punishment system, also called disciplinary system, is clearly enacted against the misconduct[6]. Those systems usually stipulate that relative punishments shall be inflicted on officials in the event that they refuse to fulfill what they should do, or that they conduct any dereliction or unlawful act while working. For instance, General Status Act for National and Local Officials, enacted in France, stipulates in Article 29 that disciplinary sanction shall be implemented on officials in the event that they violate any laws while executing public affairs or related tasks. In addition, in Japan, it is also stipulated in Article 82 of National Public Service Law and Article 20 of Local Public Service Law that official workers' dereliction and breach of their obligation shall be considered as misconduct which brings disgrace upon all the national service workers. And thus as a punishment and according to the consequences, they shall be warned, salary-cut, suspended or even dismissed from their duties. American Detailed Rules on Civil Servants' Conducts Section 5 Article 4 states that if the Committee of Civil Servants finds that some appointment or relevant employees or an occupying of some position violates the Civil Service Law, the Detailed Rules on Civil Servants' Conducts or specific regulations, it should require for explanation after notifying relevant employees and business institutions and is entitled to the introduction of facts and instruction of disciplinary punishment or expulsion to the appointing officers concerned. French General Status Law of National and Local Civil Servants Article 29 stipulates that civil servants should be sanctioned according to the disciplines for any illegal act in their performance of public duties or any situation related. 


\subsection{Legalization: the foundation and precondition of governing officials' non-action in western countries.}

In the long political tradition of western countries especially in the USA and UK, legalization is the basic part of political life in western countries. Civil servant system in western countries contains rational, law-ruled, effective, responsible and some other core values. It provides institutional guarantees for western countries to govern the officials' not doing the practical work. Western countries normalize and restrain the behavior of civil servants via improving civil servant legal system. For instance, the USA has Pendleton Act, Civil Servant Law, Position Classification law, Civil Service Reform Act, Government Performance and Results Act, Civil Servants Behavior Rules, etc. The UK has Fulton Act and civil official regulation, French has Civil Servant General Act. Singapore has Civil servant rules and Disciplinary Regulations. Through the prevention and governance of officials' not doing practical work via using these legal systems, which fully embodies legalized govern concept in western countries on the problem of officials' not doing practical work.

Western national civil services, which are based on the rule of law or are governed by the Civil Service Law and other regulations, not only provide a basis for managing officials, but also fully embody the concept of modern Western constitutionalism. And rule of law requires the administration, which opened a new era of the rule of law.

\section{Acknowledgments}

This work was financially supported by "the National Social Science Foundation of China (13CGL132)", "the Fundamental Research Funds of National School of Administration (13HZKT199)”, “the Scientific Projects of HuBei Province (2015BDF037)”.

\section{References}

[1]Information on http://www.ylqf.yn.gov.cn/info-32-10668.html

[2]Zhang Xiqing, "The definition and origin of the imperial examination" Journal of Henan University ( Social Science). 2007, Vol.47No.5:99-106.

[3]Li Tie, "Chinese examination system", China University of Political Science and Law Press,Beijing, 1989:173.

[5]Geng Jianliang, On the experience and value of performance appraisal of civil servants in the West”, Journal of Guangxi Normal University(Philosophy and Social Sciences Edition), 2010(1):132-137.

[4]Zhao Yuxia, "Reviews of foreign civil service examination system” ,Theory Study,2005 (5) :50-51.

[6]Hou Qian,Fan Weihong,“the disciplinary mechanism against civil servant abroad”, Journal of Science \& Technology Progress and Policy,2004(9):37-39. 